\title{
Between the Public and the State: The Shipping Lobby's Strategies against US Immigration Restrictions 1882-1917
}

Torsten Feys

Ghent University (FWO)

Based on Freeman's model of interest group-driven migration policies, the article gives a qualitative inside look on a neglected actor during the formative years of US immigration reform. It analyzes the central role of the shipping companies in coordinating the pro-immigration campaign with and against other interest groups. Their lobbying is divided into two complementary sections: inside top-down efforts (lobbyists) to influence legislators and outside bottom-up efforts (migrant communities and the press) to mobilize the public. It assesses the importance of public opinion in their lobby campaigns and the shipping companies' success in delaying far-reaching restrictions until 1917.

\section{INTRODUCTION}

In the spring of 2006, the United States witnessed one of its largest civic mobilizations. Millions of protesters took the streets against pending repressive immigration bills that criminalize illegal migrants. Supported by various interest groups defending immigration, the Hispanic community carried the movement. Instigated by the Spanish-language media, they reminded legislators: "today we march, tomorrow we vote." The next year, a law was considered including a major regularization program for illegal immigrants. This time, conservatives launched a massive media campaign denouncing the bill for giving "amnesty to lawbreakers" (Suro 2009, 20607; Facchini, Mayda, and Mishra 2011, 118). Suro (2009, 220) observed that press coverage on immigration in the last 30 years has been increasingly lopsided, focusing on its negative aspects. However, he also posed that thanks to new media, press coverage on immigration bills greatly increased, empowering the opposition of minorities of the public to create a stalemate 
on the issue since 1986. After the large turnout of the Hispanic vote in the 2012 elections underlining their growing electoral importance, some congressmen are currently hoping to break the stalemate.

If they succeed, this would however not be a first. As Goldin (1994, 223) observed, the perplexing part of early US immigration restriction history is not that authorities closed the gates for Europeans, but that it took so long to do it. This battle centered on bills containing a literacy test aimed at curbing the then booming movement from eastern and southern Europe. Such bills based on racial prejudice passed one of the houses of Congress 17 times between 1896 and 1917 before finally being enacted. In the meantime, 17 million immigrants, most of them "in-betweens," landed in the United States. Goldin identified four interest groups: labor unions, native rural America, capital owners, and immigrant communities, with changing coalitions. Restrictions eventually passed because of the ever-increasing support in rural America curtailing the pro-immigration votes to major urban centers where migrants concentrated (ibid., 224, 255-56).

Applying Freeman's model based on interest group-driven migration policies, Zolberg and Tichenor refined the category of "pressure groups" that were involved in the pro- and anti-immigration lobby campaigns, which showed that the involvement and motives of certain groups changed over time and sometimes led to new coalitions. Tichenor stresses the impact of institutional changes, expert narratives, and global pressures on migration policy during the Progressive Era. Yet studies remain on the surface on how interest groups lobbied and to what extent they adapted their strategies according to the changes which shaped migration policies (Goldin 1994; Freeman 1995; Tichenor 2002; Zolberg 2006). This paper addresses this gap giving a qualitative inside look on a totally neglected interest group - the shipping companies. The article uncovers practicalities of lobbying and how coalitions between interest groups were forged. It stresses the need to further distinguish the interests groups into separate factions. It suggests that shipping companies were the most consistent pro-immigration actors within the "capital-owner" interest group and coordinated the efforts of immigration advocates. The article highlights that the passage of the Literacy Test and Quota acts, what Tichenor $(2002,12)$ called the triumph of restrictionists, came when the shipping lobby fell apart due to global pressures. Freeman's (1995, 885; 2002, 7778) diffuse cost and concentrated benefits paradigm accounting for the gap between liberal policies and restrictive public opinion will be tested. Is the stalemate over the literacy test an outcome of an organized 
pro-migrant lobby winning over a resource-weak diffuse anti-migrant lobby? Or do we see, as Geddes and Statham (2006, 248) suggested, political elites tending to favor restrictions determining policies relatively autonomously over a weak civil society engagement?

Drawing their main revenue from third- and second-class migrant transport, shipping line's motives to fight restrictions are obvious. Yet as any other interest group, answering how is much more difficult due to the secretive nature of lobbying. Using the correspondence of the New York agent of the Holland America Line (HAL) with the directors in Rotterdam and lobbyists in Washington, this article answers Geddes and Staham's calls $(2006,206)$ and Bonjour's $(2011,117)$ for more empirical studies on why liberal states accepted unwanted migration. It also responds to Freeman and Kessler's call $(2008,670-73)$ for research on how interest groups mobilize and influence individuals. The lobby strategies can be divided into two complementary sections: inside top-down efforts to influence legislators and outside bottom-up efforts to mobilize the public. These evolved according to rising anti-trust pressures exposing the visible hand of corporate interests in American political and public spheres. The interest groups advocating immigration restrictions used the growing mistrust towards corporations as an integrated part of their lobby campaigns. How the shipping lobby countered the opposition by closing their ranks and mobilizing immigrant groups is discussed.

Klüver $(2013,59)$ highlighted that contemporary lobbying is a collective enterprise and its success depends on information supply, citizen support, and economic power. The collectivization of the pro-immigration lobby with special attention to information supply and citizen support will be discussed. How do pressure groups shape the relationship between the public and the politics of immigration policy? Did they stir the public opinion in general or specific segments? What role did ethnicity have on this segmentation? How did they use the media? As Bonjour $(2011,111)$ questioned, was this public opinion in all historical circumstances in favor of restrictions? Are immigration controls developed in response to the public? What can the passage of the literacy test tell us on today's deadlock around immigration reform?

\section{SHIPPING CARTELS AND THE PRO-IMMIGRATION LOBBY}

Freeman $(1995,885)$ posed that: "immigration tends to produce concentrated benefits and diffuse costs, giving those who benefit from immigra- 
tion greater incentives to organise than persons who bear its costs." As the immigrant developed into the most valuable commodity on the North Atlantic trade route, no interest group benefited more directly from the long nineteenth century mass migration than shipping companies. Keeling (2012, 284-85) showed that nearly all passengers traveling third class and the great majority of second class were migrants. First class was nearly exclusively reserved to business and leisure travel and represented about 13 percent of the total traffic. Keeling $(1999,40)$ estimated that shipping companies drew more than half of their revenues from migrant transport and less than a quarter each on non-migrant and freight transport, respectively. Followed by employers, ethnic communities, and cosmopolitans, they profited from the general assumption that immigration was essential to the growth of the United States.

As pointed out by Klebaner (1958) and later corroborated by Jones (1992) and Zolberg (2006), the shipping lobby shaped the enactment of federal migrant transport regulations, state immigration laws, and the implementation thereof before the 1880s. The shipping interests favored stalemates on the issue as generally less regulation resulted in higher benefits. To accomplish this, they played out the rivalry between Atlantic ports to attract the trade and instigated jurisdiction disputes between federal and state authorities. Yet by the 1870s, the port of New York won the battle for the trade, while the Supreme Court moved all immigration matters under federal authority. No longer being able to oppose state and federal interests, the shipping lobby resorted to the rhetoric that migration was a matter of trade subordinate to international treaties based on reciprocity. They instigated attempts to reach international agreements to stall one-sided actions. In the meantime, views that immigration came at a social and economic cost threatening the racial integrity of the nation gained momentum. The pressures spurred the growing sentiment that migration was a matter of national sovereignty which led to the first major immigration reform in 1882 (Feys 2010, 39-44).

This reform resulted in the exclusion of Chinese laborers and a first general law excluding idiots, paupers, and convicts. Up to 1917, legislation limited the Asian influx, while leaving the European flow largely undisturbed and allowing it to swell and spread to eastern and southern Europe. Even before the restrictions, transpacific migration was only a small fraction of the size of transatlantic movement, and shipping interests never reached the same importance as on the Atlantic (Heffer and Wilson 2002, 44-45). Their absence in the legislative debates on Asian immigra- 
tion stands in strong contrast with their Atlantic counterparts. By the 1880s, the transport of European migrants had shifted from sail to steam ships. Apart from reducing travel time, risks, and costs of migration, this transition led to a concentration of the migrant transport in the hands of a limited number of joint-stock companies. The American flag that dominated the migrant transport during the age of sail quickly declined, leaving the market nearly exclusively to European companies. The British took over the lead which was gradually undermined by continental lines, in particular the German Hamburg American Line (HAPAG) and the Nord German Lloyd (NGL). Lobby campaigns were initially divided between American, British, and continental shipping interests before clustering during the 1900s (Cohn 2005, 490; Keeling 2012).

The keen competition for the migrant trade led to the creation of three main passenger cartels known as shipping conferences. These collusive agreements had to mitigate competition and reduce the effects of trade fluctuations, primarily by regulating prices (Ville 1990, 95). The British companies inaugurated the practice and controlled their internal market and Scandinavia, supplemented by some continental passengers. Besides fixing ocean passage prices, the British-Scandinavian shipping conference regulated sailing dates, routes, ports of call, advertisement strategies, fixed commissions for migrant agents selling tickets, and stipulated rules to regulate their sales. Tickets were sold on both sides of the Atlantic, approximately 70 percent in Europe and 30 percent in the United States. On both continents, representatives of the companies convened frequently to ensure the compliance to the agreements and discuss general business matters in which lobbying against immigration restrictions became an integrated part. Initially the cartels suffered from internal and external pressures leading to recurrent rate wars and occasionally allowing new companies to pentrate the market (Boyce 1995; Greenhill 1998; Deltas, Sefres, and Sicotte 1999).

The continental lines organized their own shipping conference but took the agreements a step further. Drawing most of their passengers from continental Europe, they divided this market into shares. This neutralized the internal competitive pressures between the members much better, giving the continental lines an edge on the British lines for the North Atlantic migrant traffic. A third conference was established to regulate the traffic from the Mediterranean. Inter-conference agreements developed into a general pact for the entire North Atlantic migrant traffic involving 30 companies in 1908 (Murken 1922; Feys 2008; Keeling 2012). Records of passenger shipping companies have rarely been preserved or very 
poorly, except for the HAL. This work is based on the correspondence between New York head-agents and the Dutch directors in which lobbying strategies were discussed. It includes copies of the correspondence with lobbyists in Washington. For the first time in research on migration policy during the Progressive Era (1890-1920), this unique primary source addresses lobbying from the point of an interest group itself. The information relates not only to the company but also to its closest cartel partners the NGL and HAPAG. With the expansion of the cartel agreements, the correspondence gives a unique inside view on the passenger shipping lobby as whole. The fourth continental cartel partner, the Red Star Line (RSL), was initially not included in the lobbying strategies because of its American ownership. Together with its sister company, the American Line, RSL owners lobbied the US Congress to pass maritime and migration policies which would give American companies competitive advantages to the detriment of foreign lines. This explains the division between and within the shipping interests until 1902 when, due to a big shipping merger, the interests converged.

\section{INSIDE LOBBYING FROM TOP-DOWN}

The HAL established a passenger service between Rotterdam and New York during the steam-shipping boom early 1870s. As many other lines during the start-up phase, it relied on the consular corps to promote and defend the company's interests abroad. Sometimes consuls even represented the line. This consolidated the HAL's close ties with the Dutch diplomatic corps who, during the first decades, intervened in lobbying practices. Like other companies, HAL initially voiced their claims against American immigration laws through their diplomats. They defended the rhetoric that migration depended on trade treaties and dragged negotiations for an international agreement on transatlantic migrant transport, including international courts to enforce the pact. The negotiations served predominantly to stall national migration reform in the United States between the late 1860s and 1880s. Passenger shipping interests provided diplomats with arguments and means. The 1882 immigration law put an end to this, establishing a turning point also for European countries and their diplomats who now recognized migration control as a matter of national sovereignty. Contesting the right of who was getting in was no longer conceivable, yet passenger acts regulating how migrants were transported remained disputable. Congress had also passed new space, hygienic, 
and food requirements reducing the capacity of the ships with the new Passenger Act (1882). The Dutch envoy in Washington, G. de Weckherlin, advised against fighting the provision by claiming that Dutch ships abided their own national laws and challenged the jurisdiction of US authorities on Dutch vessels. Protesting against a humanitarian measure was delicate. Weckherlin suggested reopening the negotiations for an international treaty. He was backed by his Belgian, Italian, and French colleagues and the US secretary of state, F. Frelinghuysen. Yet the initiative was compromised by the German and English interests who presented a joint resolution to unify the American passenger acts with theirs. A congressional commission investigating this resolution obstructed the efforts to reach a broader international convention. ${ }^{1}$

Throughout the 1880s, this remained a contested issue. Weckherlin represented the Dutch shipping lines in court cases regarding violations of the US Passenger Act. The diplomat also supported propaganda campaigns to defend the reputation of Dutch passenger lines among the American public. $^{2}$ Yet with the viewing of immigration as a national sovereignty matter, diplomats became reluctant to intervene on behalf of shipping companies. The latter increasingly relied on lobbyists to defend their interests in Washington. These were generally recruited from specialized law firms and preferably had served as congressman before. Former Senator Roscoe Conkling worked for the shipping interests during the 1882 migration reform. He was held responsible for the veto of his former protégé, President Arthur, against a radical version of the Passenger Act. In his message, Arthur stated that it imposed excessive losses on shipping companies. In the end, Congress adopted a milder version closer to European passenger acts (Hutchinson 1981, 78-79; Jones 1989, 329; Zolberg 2006, 192-93).

In the mid-1880s, the HAL hired a full-time lobbyist, George Glavis, described as "the lobbyist of the Conference Lines knowing all the inside tracks." He replaced Weckherlin in courts and before the Treasury Department. He also functioned as spokesman in Congress. Glavis monitored all congressional debates on migration and maritime issues. Representing the

\footnotetext{
${ }^{1}$ G. de Weckherlin to Dutch Ministers of Foreign Affairs, letters and reports, May 4, June 29, July 3, and August 14, 1882, February 16, March 28, April 14, 16, and 30, May 18, and June 5, 19, and 20, 1883, and April 12, 1884; Dutch National Archives, Gezantschap USA, 2.05.13, 210; New York Consul C. Mali to Minister of Foreign Affairs W. FrèreOrban, correspondence, February 16 to July 28, 1883; Belgian Ministry of Foreign Affairs Archives, Emigration, $2961 \mathrm{I}$.

${ }^{2}$ Ibid.
} 
German lines as well, he conferred with the three shipping companies on a joint line of action. The lobbyist distributed arguments against restrictions among congressmen. The establishment in 1889 of special immigration committees in the House and Senate to evaluate bills opened new doors for interest groups to influence legislation. Glavis organized the hearings of the shipping lobby at the immigration committees, inviting experts to defend the liberal cause. Similar hearings were organized before the president when a veto was solicited. When it seemed likely that a law would pass, the lobby stalled action on it by introducing amendments, bringing up other issues for consideration, filibustering or claiming the need for an investigation commission to collect more information. In the latter case, Glavis made sure that people defending the interests of the shipping lines sat in these commissions. If these measures did not prevent the bills from being considered, the lines weakened its negative impact as much as possible. Glavis provided congressmen with amendments which safeguarded the interests of passenger companies. At their expense, the lobbyist organized dinners and distributed gifts and free passages to Europe to create goodwill. He also channeled contributions to campaign funds of both Democrats and Republicans. To make sure that the laws that did pass were implemented in their favor, Glavis also lobbied for the appointment of liberals at key positions in the federal immigration administration established in $1891 .^{3}$ In particular, the commissioner general of immigration leading the administration in Washington and the commissioner of immigration of New York leading Ellis Island — both designated by the president — were key. The shipping lines sometimes got their way as with the appointment of Robert Watchorn at Ellis Island. Other times they did not, as with his predecessor and successor serving two terms, the nativist William Williams. Yet Williams was forced to resign during his first term following a press campaign crafted by the pro-immigration lobby, bringing him disrepute. A similar attempt during his second term was less successful (Feys 2013, 271-76, 306-11).

This surge of the so-called "third house" allowing lobbyists to gain importance as middlemen between politicians and corporations has to be seen against the background of institutional changes, shifts in party politics, the rise of progressivism, and new waves of nativism. A new form of political organization took shape around the turn of the twentieth century.

\footnotetext{
${ }^{3}$ Head agency New York to directors Rotterdam, Correspondence 1883-1902, Municipal Archives Rotterdam (MAR), Holland-Amerika Lijn (HAL) collection, 318.02 Directors, 112-121; 318.04 Passage, 221-26.
} 
Besides elections and protest movements, direct involvement in legislative activity was emerging as a model for popular political participation. This involvement was less guided by partisan loyalty which was in decline, but ever more by interest groups which mobilized voters (Clemens 1997, 1-5). To asses this, Clemens reminded us that how interest groups organized is equally as important as why. Tichenor (2002, 30-33) underlined the importance of changes both within and between institutions which created opportunities to exercise influence. Group alliances opposing immigration restrictions were faster to adapt to these changes than their counterparts. Also their role in influencing expert narratives and their reaction to global pressures will be addressed to complete Tichenor's (2002, 49) suggested processes of analysis shaping immigration policy making during the Progressive Era. The new currency of political influence included top-down procedural mastery and technical expertise which lobbyists increasingly coordinated in Washington. A third new political currency, the mobilization of the public opinion, is of a bottom-up nature (Clemens 1997, 2-4). How shipping companies relied on journalists and voluntary associations representing migrant communities for this is the next point of analysis. Such voluntary organizations, often having formal committees to draft legislation, lobby, and cultivate public opinion, boomed during the Progressive Era. They helped individuals formulate their demands and monitor how politicians acted on them. For their part, politicians became more able to create ties to these electoral blocs and become less dependent on party leadership (Clemens 1997, 1-8).

\section{OUTSIDE LOBBYING FROM BOTTOM-UP}

Campaigns in Washington carried much further when supported by the public. Through advertising, shipping companies had close ties with the press. As Mora $(2005,29-31,337-39)$ underlined, the rise of mass media gave public opinion a forum to develop and went hand-in-hand with the beginnings of mass advertisement campaigns. At the same time, mass media became the place of predilection of pressure groups to voice their arguments and influence both public and politicians alike. Most of the advertisement budget of the passenger lines targeted cabin-class passengers and went to the bigger newspapers such as the New York Herald, Times, Tribune, Sun, the Washington Post, or Chicago Tribune. Another part of the budget went to the foreign-language press. Migrant-class advertisement was mostly left to the migrant agents. HAL had 1,250 to 2,000 agents 
representing them in all parts of the United States. These agents combined the sale of ocean passage tickets with migrant-specific banking services, in particular remittances. Often other types of related business were added ranging from notaries, real estate agents, saloon keepers, and grocers. Newspaper owners represented an important subcategory. In this foreign press, migrant agents advertised their agency and the shipping lines they represented. Conference rules prohibited advertisements to contain comparisons between companies and tried to limit their amount to neutralize competition. They withdrew all advertising from papers that openly attacked the interests of the shipping conference (Dillingham report vol. 37, 1911; Jones 1992, 195; Day 2002, 77-78; Feys 2013, 110-13).

Shipping lines used these connections when pressures to restrict migration increased. In the wake of the 1892 cholera epidemic, migrant traffic was temporarily suspended. Restrictionists led by Senator W. Chandler used the momentum to demand a one-year immigration stop to prepare restrictive reforms. The NGL, HAPAG, and HAL appointed a commission that screened the press for newspapers agitating against them. They hired journalists to answer the hostile articles, write, and collect propaganda to distribute among newspaper editors. The campaign centered on western states depicting restrictions as a scheme of eastern interests to hamper the development of the West. As the New York head-agent of the HAL reported:

\footnotetext{
The Eastern gutter press predicts that the law will pass, while more serious papers don't mention it. The secret agitation of the shipping lines out of Washington targeting the western voters through local western papers triggered an important wave of protest against restrictions. Western Senators and Representatives will not dare to vote in favor of the Chandler Bill unless a new wave of cholera brakes out again. ${ }^{4}$
}

Chandler blamed the shipping lobby for the successful agitation against his plans and called restrictionists to organize to form a counterbalance (Chandler 1893, 3).

\section{IMMIGRATION RESTRICTION LOBBY AND THE RACIALIZATION OF EUROPEAN MIGRATION}

This corroborates Freeman's assertion $(1995,885)$ that interest groups benefitting from immigration were better organized than those who bear

\footnotetext{
${ }^{4}$ Head agency New York to directors Rotterdam, Letter October 8, 1891, MAR, HAL, 318.04 Passage, 221.
} 
the costs. Labor unions may have been the biggest pressure group, and they took much longer than shipping companies to openly take a stance and lobby for restrictions on southern and eastern European migration (Goldin 1994, 224; Clemens 1997, 5). Terence Powderly, leader of the Knights of Labor, labeled new immigrants as "semi-barbarian" who accepted degrading living and working conditions because they had no intention to become Americans, but returned home. Powderly accused them of lowering American standards (Powderly 1888, 165-74). This political claim countered the image of the immigrant as the cornerstone for the wealth of the nation. By the mid-1890s, the biggest union, the American Federation of Labor (AFL) took over the rhetoric and endorsed restrictions, yet its membership remained divided on the issue. Part of the intellectual community provided scientific arguments to motivate these nativist claims. Already in the 1880s, members of the American Economic Association suggested a literacy test to reduce immigration from new regions while keeping the gates open for northern and western Europeans. A group of Harvard intellectuals institutionalized this elitist movement by founding the Immigration Restriction League (IRL) in 1894 (Bemis 1888; 251-64; Higham 1955, 112-13; Jones 1992, 188-92; Tichenor 2002, 76-83; Zolberg 2006, 194-211).

The IRL transcended party politics and created the first lasting platform for restrictionists. Its lobby strategies greatly mirrored those of the shipping lines. For the outside bottom-up campaigns, they screened the press producing a list of 500 papers willing to propagate their ideals. To stir the public, IRL members organized speeches and distributed pamphlets. For the inside top-down campaigns, they opened an office in Washington headed by James Patten. He distributed information and law proposals among congressmen. The lobbyist coordinated the immigration restriction lobby at the hearings of the House and Senate immigration committees, where their efforts concentrated. The IRL used scientific arguments and participated in the academic debate. The movement constantly denounced the shipping lobby for sabotaging restrictions for pecuniary gain, while being unconcerned about the country's future. To get their hands-on compromising proofs, they hired private detectives. The IRL founded its political claim on ethno-cultural differences stating that the United States was committing racial suicide through unrestricted immigration. They advocated the literacy test which was introduced by their voice in Congress, Senator Henry Lodge. Labor unions supported the campaign for this educational test bill, the first organized lobby effort 
against immigration in this era (Higham 1955, 103-07; Tichenor 2002, 16-17, 76; Zeidel 2004, 17; Feys 2013, 252).

That this happened during an economic downturn when migrants were an easy scapegoat is no surprise. It also explains the near success of the less experienced anti-immigration lobby. The category of "capitalist owners" referred to by Goldin $(1994,253)$ and Tichenor $(2002,82)$ in theory should include shipping interests, but in practice coincides with American employers and industrialists. They point to a near absence of pro-immigration interest groups stating that employers refrained from lobbying against restrictions because of the 1890 s economic downturn. Neither explain how employers lobbied before requiring further study, yet foreign shipping companies corroborate this drop of support in their campaign against restrictions and forced them to resort to expand their lobby efforts. The continental lines depending more heavily on southern and eastern European migrants (HAL, NGL, and HAPAG) led the charge as they risked losing 30 percent of their steerage passengers. The British lines transporting mainly literate British and Scandinavians felt less concerned as they only risked losing 3 percent of their business. They declined a joint-lobby effort, yet opposed the literacy test through their own channels. To counter the IRL, the Continental lines hired two Washington journalists who worked as correspondents for various prominent American newspapers at $\$ 80$ per week to agitate in favor of migration. Glavis' annual salary was raised to $\$ 9,000$ to intensify his efforts. The costs were divided between the lines based on the number of passengers carried. The shipping companies relied on the foreign-language press and the migrant agents to mobilize the public, in particular the immigrant communities. ${ }^{5}$ Efforts concentrated in western and southern states as a cable from the NGL to western migrant agents and ethnic associations underlined:

Immigration bill comes up in House on Wednesday; wire your congressmen, our expense, protesting against proposed exclusion and requesting bill be defeated, informing him that a vote in favor means defeat in next election. ${ }^{6}$

${ }^{5}$ Ibid. Letters July 17, 1895, and January 28 and February 14, 1896; 318.02 Directors, 112-121.

"Foreign Steamship Agitation against the Immigration Restriction Bill," IRL circular February 22, 1897; Harvard Open Collection Program (HOCP): Immigration 17891930. 


\section{Anti-Trust Movement and Ethnic Mobilization}

The restrictionists got their hands-on NGL's cable and published it widely. Their education bill passed the House and Senate in 1896. President Cleveland rejected the "un-American" bill, and although the House overrode his veto, the Senate buried the act. Restrictionists attributed its defeat to the German-American community which, however, would have remained largely unaffected by it. The IRL produced pamphlets that this support had been obtained by the shipping companies that portrayed the bill as an Anglo-Saxon scheme to cripple the German-American element. ${ }^{7}$ Shipping lines chose to do so because the targeted immigrant groups from southern and eastern Europe were less established to voice their protest. Conversely, no ethnic community was better organized and had more political weight than the German American. The continental lines supported many German-American associations through membership or advertising to retain close ties with their pioneering client base. The British lines used the same strategies as they spent their "educational fund," named after the bill, to stir protests among the influential Irish community rather than new immigrant groups (Martin 2003, 134; Feys 2013, 259). The defeat of the bill spurred by old-stock immigrant communities gave the opportunity for newer ethnic groups to swell their numbers, organize, and gain political influence. Russia, the Austrian-Hungarian Empire, and Italy accounted for 90 percent of these "in-betweens," as Roediger (2005) labeled them for not being considered as fully white neither as nonwhite (Keeling 2012, 23). It allowed them to initiate a long struggle to get recognition of equality with their predecessors from northern and western Europe and to achieve full "white status." Despite varying degrees of whiteness among the European migrants, Guglielmo (2003, 28-30) underlined that the newcomers never lost their "white on arrival" voting privileges. After a five-year residency, they could obtain citizenship and with it gain political power to climb up the "socio-ethnic" ladder.

Shipping interests stimulated this process by helping defeating the educational bill by a small margin. Yet their ability to openly fight restrictions decreased because of the growing fears of the public toward the ascendency of big business and the passage of the Sherman Antitrust

\footnotetext{
${ }^{7}$ Ibid. IRL to newspapers, letter January 25, 1898.
} 
Act (1890) which had to protect the public from monopolies. Shipping conferences initially managed to evade the anti-trust radar, yet after the turn of the century it came under increased scrutiny (Chandler 1977, 172; Bittlingmayer 1996, 375-78). The IRL's accusations of being the driving force behind the pro-immigration lobby and defending predominately foreign business interests undermined the shipping lobby's campaigns. They could not deny that pecuniary gains were their main motive making their direct interventions during the trust-busting climate increasingly delicate. Their campaigns would gain much more credibility if expressed by ethnic communities the HAL head-agent in New York reported:

\begin{abstract}
Hoping that the ameliorating economic conditions will turn the public opinion in favor of immigration, to influence it and go up against the IRL, the HAPAG and NGL elaborated a plan to establish a Pro-Immigration Leaugue. Joseph Senner, journalist and former Commissioner of Immigration of New York has been appointed to lead the League and set up branches nationwide. He will travel throughout the country, hold lectures and recruit members, especially in the West. [...] To cover up our involvement, the League will distance itself completely of the steamship lines and even create the impression to oppose us. [...] The Germans asked to contribute, yet not to mention it to any other lines out of fear that it may leak out. ${ }^{8}$
\end{abstract}

Aiming to recruit as many members as possible, membership only cost a symbolic dollar. Shipping lines provided the funding paying Senner's salary and expenses. The Austrian-born had the perfect profile to lead the propaganda campaign. He was a former editor of the New York Staats-Zeitung. Senner also helped introduce the literacy test in Congress when heading Ellis Island and was known for his stance against the shipping lines. Contrary to what leading scholars have assumed, not the associations representing various ethnic and nationality groups, but shipping companies formed the cornerstone of the Immigration Protective League (IPL). Conversely to what Tichenor states, the IPL did not mirror the IRL but profited from the long-standing lobby experience of the shipping interest and functioned as their mouthpiece (Senner 1894, 499, 1897, 8; Higham 1955, 107; King 2000, 56; Tichenor 2002, 81-83; Zeidel, 2004, 12; Zolberg 2006, 222).

${ }^{8}$ Head agency New York to directors Rotterdam, letter November 16, 1897. MAR, HAL, 318.04 Passage, 221-26. 
Figure 1: US Immigration Reform for European Migration and the Literacy test during the Progressive Era

\begin{tabular}{ll}
\hline 1882 & Immigration Act (excluding: people likely to become a public charge, idiots and convicts) \\
1884 & Contract labor law (excluding contract laborers) \\
1891 & Immigration Act (excluding: polygamists, people with contagious \& loathsome diseases) \\
1896 & Bill containing literacy test passes Senate and House \\
1897 & Presidential Veto against Literacy test \\
1898 & Literacy test passes Senate but not the House (appointment of Industrial Commission) \\
1902 & House passes a Literacy test, but dropped from bill in Senate \\
1903 & Immigration Act (exclusion of anarchists, prostitutes, the insane and epileptics) \\
1906 & House drops the Literacy test in favor of investigation commission \\
1907 & Immigration Act (appointment of Dillingham Commission) \\
1913 & Presidential Veto against Literacy test \\
1915 & Presidential Veto against Literacy test \\
1917 & Presidential Veto overridden: Immigration Act containing Literacy Test \\
$1921 / 24$ & Quota Acts \\
\hline
\end{tabular}

Senner challenged a new version of the educational bill as a threat to the future of German schools, language, churches, and newspapers. At the top of the IPL Oscar Strauss, a progressive Jew and Bourke Cockran, a prominent Irishman, joined to transcend ethnic and religious boundaries. IPL reached out to the entire immigrant community through mass meetings and the press. The bill passed the Senate, yet Glavis reassured that President McKinley would prevent it from being considered in the House. Catholics and foreign-born citizens had supported his rise to power, and he did not want to ignore their protests. Instead, German-born Republican Richard Bartholdt successfully introduced a bill for a commission to investigate and recommend legislation to meet the problems created by industrialization and immigration. Bartholdt, a former journalist and newspaper editor, was one of the continental lines' inside men in the House (1893-1915). He helped pro-immigration forces in their battle with restrictionists to influence the appointment of the members of the Industrial Commission consisting of 10 congressmen and nine expert civilians. It took three years to complete its report stalling any far-reaching legislation on immigration (Hutchinson 1981, 124-25; Just 1988, 224; Lissak 1994, 220-21; Zeidel 2004, 20-34).

\section{CONSOLIDATION OF THE PRO-IMMIGRATION LOBBY}

The Industrial Commission relieved the pressures on immigration advocates resulting in the dissolution of the IPL. Shipping lines no longer considered

${ }^{9}$ Ibid. Letters March 11, and May 13, 1898. IRL to newspapers, circular January 25, 1898. HOCP, Immigration 1789-1930. 
the situation to warrant the expenditure and suspended their financial support. The commission did not recommend a literacy test. The shipping lobby influenced these suggestions in the House through William Shattuc, chairman of the committee of immigration. Nevertheless, restrictionists managed to add a literacy test amendment. To oppose it in Congress, the HAL, HAPAG, and NGL relied on Claude Bennet who substituted the deceased Glavis. Through his Congressional Information Bureau, Bennet provided detailed reports on congressional debates and off-the-record opinions on maritime and immigration issues. To defend their interests at the congressional immigration committees, they now relied on A. Anderson of the American Line. Under the impulse of JP Morgan, one of the biggest shipping mergers on record was established in 1902, the International Mercantile Marine Company (IMMCO). The American initiative to regain maritime control over the North Atlantic came about partly because of the conviction that Congress would adopt policies giving it competitive advantages over foreign lines. When this failed, the combine turned into a multinational initiative formed around British and American lines but also included a profit sharing agreement with the HAPAG and NGL which was part of the deal bought in a controlling interest of the HAL. This had a merging effect on the lobby efforts of the North Atlantic passenger lines. Anderson now represented most of the shipping companies in Congress. He received assistance of lawyer lobbyists working for the shipping lines such as Lucius Beers and Sam Neale. The companies coordinated their lobbying activities through a special "immigration law committee." Other special committees such as "Immigrant inspection," "Southern states," or "Ellis Island" underline how shipping companies closed their ranks and targeted to influence not only the enactment, but also the implementation of the laws. ${ }^{10}$

The "immigration law committee" coordinated the protest of other interest groups in Washington including immigrant communities, railroads, employers, and manufacturers which now supported the efforts until World War I. The economic upswing explains their renewed involvement in the debates after 1898. Also the sources of foreign shipping lines may underrate the connections between American capitalist and shipping interests. Sources of American shipping interests would probably show stronger ties. Once the conflict of lobbying interests between foreign and American shipping interests were appeased after the IMMCO merger

\footnotetext{
${ }^{10}$ Head agency New York to directors Rotterdam, Correspondence and reports October 18, 1902, to October 25, 1905. MAR, HAL, 318.04 Passage, 72-77.
} 
and the entry of Morgan in the shipping business, ties with American capitalist and employers consolidated. This is illustrated by the creation of the National Civic Foundation (NCF). Led by Senator Mark Hannah, known for his close ties with American shipping interests and Morgan, the NCF tried to reconcile business interests with the public and labor unions. Promoting liberal migration policies was high on the agenda.

With the "southern states committee," the shipping lines spurred pro-immigration sentiments in the South where state-sponsored immigration bureaus revived. The Senate dropped the literacy test amendment when enacting the immigration law of 1903. Anderson still complained to Shattuc, who countered by stating that the law had been stripped of the most detrimental features for the shipping lines while ensuring no further action in the near future. In his own words recorded in congressional records: "He [Anderson] wrote most of the bill. He ought to be satisfied with it" (Ward 1907, 590). Immigration remained a hot topic in the press with the New York World and New York Herald branded as agitators for restrictions. Other papers denounced the hypocrisy of both newspapers whose founders were both immigrants. ${ }^{11}$ By 1906, a new general immigration bill including a literacy test was passed by the Senate.

Armed with a fund based on a 10-cent contribution per third-class passenger carried to the United States in 1905, the shipping lobby retained its success formula. It relied on influential congressmen holding key positions; maximized their close ties with the press to "educate the public"; targeted southern and western states; and mobilized the corporate interests and immigrant communities. Old-stock immigrant groups continued to send delegations to Washington to protest against the test. The German-American Alliance and Catholic Ancient Order of Hibernians were now joined by new immigrant associations such as the Philadelphia Italian Society, the Hungarian Republican Club, and the Federation of Jewish Organizations. In the meantime, a new cross-ethnic, nonsectarian, and nonpartisan organization was founded to substitute the IPL. The National Liberal Immigration League (NLIL) started off as a Jewish initiative but soon included Irish-, German-, and Italian-born representatives. Various religious leaders joined, as did some prominent academics such as Charles Elliot and Woodrow Wilson, presidents of Harvard University and Princeton University, respectively. Politicians, Democrats and Republicans alike, also became members such congressmen Joseph Can-

\footnotetext{
${ }^{11}$ Ibid., letters May 9 and June 9, 1905.
} 
non and William Bennet. Louis Hammerling of the American Association of Foreign Language Newspapers (AAFLN) also filled the ranks. The NLIL played a crucial role in outside lobbying. The headquarters in New York soon branched out nationwide. Through mass meetings and press campaigns, it created awareness on the immigration restriction issue among ethnic groups and mobilized its participation. It united organizations nationwide to adopt resolutions against restrictions and send letters to congressmen. The NLIL also appointed a lobbyist in Washington, James Curley, for inside lobbying purposes. These were orchestrated by the league's financers, the shipping lines, and big businessmen such as Andrew Carnegie. The efforts paid off as the literacy test was substituted by a congressional investigation on immigration in the new immigration law (1907) (Lissak 1994, 208-23; Zeidel 2004, 27-32). ${ }^{12}$

The Dillingham Commission stalled immigration reform for four years. The pro-immigration man on the commission, William Bennet, successfully defeated Lodge to extend the research as far as possible to delay legislative action. However, he could not prevent the commission to recommend the literacy test as the "most feasible single method of restricting undesirable migration." The IRL's propagation of social Darwinism was clearly present in the commission's conclusions. Already before the turn of the century, the IRL contributed to the introduction of a list of races and people that classified newcomers at the gates not only by country of origin, but also by racial and ethnic background. This enhanced the differentiation of Europeans into various degrees of whiteness which was based on Ripley's book Races of Europe, attributing superior racial features to old-stock immigrants. It facilitated the task of immigrant inspectors to apply the existing immigration laws more strictly on southern and eastern Europeans. The commission hired the anthropologist Franz Boas to investigate Ripley's assumptions and refuted the racial inferiority of new immigrants attaching more importance to cultural than biological determinants for differences. The IRL discredited Boas for being a lapdog of the shipping interest, pointing to his family ties with the HAPAG New York head-agent Emil Boas. This may have influenced the Dillingham Com-

${ }^{12}$ Ibid., Correspondence from January 1905 to December 1907. 318.02 Directors, 112121, 318.04 Passage, 72-77; Hammerling to Department of Commerce and Labour, September 8, 1909. National Archives Washington (NAW), Immigration and Naturalization Service (RINS) 1787-1998, RG 85, 52600/13, Investigation at Ellis Island 1909; Correspondence 1907 to 1916, NAW, RINS, RG 85, 51632/13, National Liberal Immigration League. 
mission who ignored Boas' conclusions (King 2000, 61-70; Weil 2003, 271-96; Zeidel 2004, 101-14).

\section{THE GROWING IMPORTANCE OF PUBLIC OPINION AND THE PRESS}

The IRL distributed thousands of copies of the report's summary, feeling confident to make an end to the "foreign communities, foreign shipping lines and foreign-language newspaper's efforts" which made sure that "there are much more stringent regulations to import cattle, sheep, hogs, dogs and horses than human beings" (Ward 1910, 56-57; Hall 1912, 94-102). Depicting business interests as interfering with national welfare was a popular strategy to gain support for one's cause during the Progressive Era. The IRL may have tended to exaggerate the role of shipping companies who it designated as their main opponent, yet it is undeniable that the accusations had strong factual roots. IRL's instigations contributed to the appointment of a congressional committee investigating illicit lobby practices, but the investigation did not uncover strong incriminating evidence against the shipping lobby. ${ }^{13}$ In the meantime, new ethnic organizations gained maturity as illustrated by the American Jewish Committee's sponsored economic research which refuted the Dillingham Commission's conclusions (Hourwich 1912).

Also the foreign-language press became better organized after attaining the height of its boom with 3,500 new papers appearing between 1883 and 1920. The papers did not escape the general trend of becoming increasingly commercialized and moving ideologically toward the center. Spurred by the control over advertising revenues, press monopolies established themselves in most American cities. In particular, the foreign-language press fell under commercial control. The advertising agency AAFLN was founded by corporate interests and the Republican Party to endorse William Taft's 1909 presidential campaign under the immigrant community. Headed by Hammering, the association claimed to reach 32 million during its apogee. The AAFLN provided political and commercial ads, but also editorials and news materials which shaped the political, social, and economic orientation of 205 papers in 1908, 508 by 1912, and 813 in 1916. Shipping lines also entrusted the advertising and

\footnotetext{
${ }^{13}$ Ibid. correspondence 1910 to 1912.
} 
lobby campaigns to the AAFLN (Ewen 1976, 62-65; Tichenor 2002, 131; Petit 2010, 66-67). ${ }^{14}$

President Taft's campaign for reelection coincided with congressional consideration of new bills based on the Dillingham Commission's suggestions. To capture the foreign-born vote, Taft declared he would veto any bill containing a literacy test. He relied on former Congressman William Bennet and on the AAFLN to consolidate his ties to foreign-born communities. The shipping lines also hired Bennet to lobby in Washington. There the minority base against restrictions grew thinner. In 1907, court decisions ruled the recruiting campaigns of southern states to be in violation of the immigration law. After the ruling, the racial tensions against migrants from southern and eastern Europe in the South radicalized. This pushed the majority of the southern congressmen to switch sides and endorse the literacy test. Instead of relying on the geographic internal division of the country, Bennet now instigated religious differences. He relied on the Catholic members of Congress. At the hearings in Congress and the White House, ethnic groups were joined by Catholic representatives such as cardinals James Gibbons and John Farley. The NLIL presented the president a petition against the bill signed by 400,000 people nationwide. Despite losing the elections, President Taft kept his word and vetoed the bill. The Senate overrode his veto, but the House failed to do so by a small margin (Hutchinson 1981, 154; Lissak 1994; Tichenor 2002, 135-37; Zeidel 2004, 124). ${ }^{15}$

In the meantime, the American anti-trust fever hit the shipping world. Congress appointed a commission lead by Joshua Alexander to analyze the monopolistic tendencies in the shipping industry. Freight and passenger lines agreed on more transparency and started a large-scale $\$ 72,000$ propaganda campaign to explain their business operations to the American public. ${ }^{16}$ It presented facts on the benefits of shipping conference agreements for the US economy and convinced the public of their honorable intentions through the idea that "the only effective channel to reach the people and move the public opinion - the news columns of the

${ }^{14}$ Ibid. Letter March 16, 1915, 318.02 Directors, 233.

${ }^{15}$ Ibid. Letter February 13, 1913, 318.02 Directors, 120. Letters December 17 and 18, 1912, January 17 and 21, February 4, 13, 15, 18, and 20, 1913, 318.03 Passage, 48-58, 97, 160, 190. The New York Times (NYT). "Taft sits as judge on the immigration bill" and "Immigration Bill in Doubt" February 7 and 14, 1913.

${ }^{16}$ Ibid. Letters December 18, 1911, January 18, March 4 and 5, April 6 and 12, June 18, 1912, 318.02 Directors, 112-121. 
American press." They chose factual rather than argumentative magazine and newspaper articles prepared by writers of reputation to increase the chances of being picked up by newspaper editors:

\begin{abstract}
The American people would resent any attempt of the steamship or any other sort of interest, to control the course of legislation secretly or by improper methods. Much of the feelings against great corporations in the US, is due to the belief that in the past these corporations have been able to influence legislation in their own interest by secret relations with legislators, by heavy contributions to campaign funds, and by attempts in one way or another to subsidise the press. To the open presentation of facts through legitimate channels, on the other hand, there is no popular objection. In fact it is coming to be recognised as the only effective means of placing any question of public interest and importance before the people. ${ }^{17}$
\end{abstract}

The shipping lines' representatives taking charge of the campaign underlined that congressmen responded to public sentiment. Passing legislation through Congress that opposed it, even if facts proved the public sentiment to be wrong, was very difficult. They argued that educating the public had become a responsibility of the corporations. No immediate reversal of the public opinion was to be expected, but the efforts would pay off in the long run. The lines also openly collaborated with Alexander's committee. This resulted in a joint publication of steamship men and academic specialists of Alexander's committee in the Annals of the American Academy of Political and Social Science 55(1) in 1914. It explained and defended the need for shipping conferences for the broader public. It expressed the committees' conclusions which only opposed some minor features of the conference system. This underlined the growing importance of public opinion and acting according to "public interests," but also highlights the significance of scientific opinions to assess policies which characterized the Progressive Era. ${ }^{18}$

\title{
THE DOWNFALL OF THE PRO-IMMIGRATION LOBBY
}

The open communication related to business practices such as pooling, price-fixing, rebates, or fighting steamers, but not to their lobby campaigns against immigration restrictions. The Alexander investigation increased

\footnotetext{
${ }^{17}$ Report of special committee of steamship lines engaged in foreign trade, June 22, 1913, 318.02 Directors, 120.

${ }^{18}$ Ibid. Reports April 15 and June 22, 1913, and letter head agency to directors April 6, 1914.
} 
lobby efforts as all conference passenger lines closed their ranks even more. Yet President Wilson's declaration to veto any bill containing such a test did not discourage the IRL. With the outbreak of World War I and fastdropping overseas immigration rates, the issue no longer seemed pressing. To prevent their cause from losing momentum, the IRL hired a publicity agency, the Far Eastern Bureau, and a publicity agent, Mr. Fairbaten. They spread the belief through the press that an unprecedented immigration wave from Europe and Asia would follow when peace returned. To give their arguments academic credibility, the IRL paid Professor Jeremiah Jenks to publish propaganda articles. Living in the general assumption that the war would not last long, the IRL underlined the urgency of adequate legislation. Bennet refuted the predicted migration tsunami through historical evidence showing that migration did not increase after previous wars. ${ }^{19}$

Yet WWI totally disrupted the pro-immigration lobby. Some shipping companies belonging to the Central Powers such as HAPAG and NGL immediately suspended their service because of the maritime blockade. Many vessels from Entente Powers were requisitioned, diminishing their service. Sea mines and submarine warfare put further strains on the North Atlantic traffic. Neutral lines such as the HAL were still able to retain their regular service until 1917. Immediately, most shipping companies struggled with an acute cash flow problem. The German lines cut wages of personnel in half and stopped all advertising. Other lines still in service strongly reduced their advertising campaigns. If the American press was ever "muzzled by steamship advertising" as claimed by the IRL, the war weakened the financial ties between the press and shipping interests (Hall 1913, 748). More importantly, the conflict undermined the shipping cartel agreements, and by 1915, the British lines withdrew from the Mediterranean and Continental conference, quickly succeeded by all other companies. Only the British-Scandinavian conference remained operative. The war totally disrupted the organization of the joint shipping lobby efforts and crippled its financial strength being at its weakest when a new educational bill passed Congress. ${ }^{20}$

${ }^{19}$ Ibid. Letter March 10, 1914. Minutes of IRL meetings September 24, October 23, November 27, December 11, 1914; Circulars IRL by Prescott Hall January 5, 6, 14, and 19, 1915. HOCP, Immigration 1789-1930. The New York World, s.t., September 14, 1914, and The New York Sun, "Effect of European war on Migration" October 25, 1914. NAW, RINS, RG 85, 53854.39 A-E, Immigration WWI.

${ }^{20}$ Head agency New York to directors, Letter August 18, 1914, MAR, HAL, 318.02, 121, and Letters December 25, 1914; January 26, February 19 and 27, March 12, 1915, 318.03 Passage, 232-235. 
One of their mouth pieces, the NLIL was also in decline. It suffered from the personal financial collapse of its president, Edward Lauterbach. It symbolizes the decline of migrant communities as an interest group. The war stirred nationalism among the immigrant groups, weakening the cross-ethnic cohesion the NLIL advocated. The German-American community lost its influence, especially after the sinking of the RMS Lusitania. American nationalism stirred anti-immigrant feelings. The movement's influence was dealt another blow when the AFL published documents on contributions paid to NLIL by industrialists, railroads, and shipping corporations denouncing it for defending big business interests (Lissak 1994; 231-35). At the hearings in the White House on a bill containing a literacy test, the pro-immigration lobby was notably less organized than before the war. Nonetheless, the former NLIL member, President Wilson, vetoed the bill for going against America's tradition as land of opportunities: "it excludes those to whom the opportunities of elementary education have been denied [...] it is not a test of quality of character or of personnel fitness, but a tests of opportunity. Those who come seeking opportunity are not to be admitted unless they already had one of the chief opportunities they seek, the opportunity of education. The object of such provision is restriction, not selection." ${ }^{21}$

With only five votes in the House preventing the veto to be overridden, the IRL and AFL tasted blood. Now rooted in an "America for Americans" rhetoric, they enhanced their campaign. ${ }^{22}$ All this while NLIL was scratching for funds asking the HAL to increase its annual contribution slightly to $\$ 2,500$. Already in 1913 , the HAL had raised its contribution, praising the league for its excellent work in mobilizing public opinion and spreading information on the benefits of immigration. The HAL still considered the NLIL as a crucial partner to fight restrictions and together with the Cunard Line and NGL continued their support despite the NLIL declining activity and influence. This refutes Lissak's $(1994,237)$ suggestion that the financial support from businessmen was individual, sporadic, and, after 1913, insignificant. From the start, shipping lines supported NLIL financially and logistically until the end. Midway in 1916, the shipping lines also mobilized the railroads who committed to fight the educational bill. Under the lead of

\footnotetext{
${ }^{21}$ Ibid. Letters January 31, February 1 and 4, 1914, 318.03 Passage, 232.

${ }^{22}$ http://www.history.umd.edu/Gompers/quotes.htm\#IMMIGRATION, accessed on March 122013.
} 
HAL and Cunard Line, the companies sent out representatives throughout the country to stir the public. The local migrant agents arranged meetings with politicians, members of merchant and manufacturers associations, etc. Surprisingly, no meetings with ethnic associations were mentioned, which suggest their fading influence. The lines therefore focused their efforts on mobilizing industrialist interests. The general impression was a lack of awareness of the disadvantages of the bill among the associations. Most also seemed unaware of how their representatives had voted on the last educational bill. There was a general lack of interest for the issue among industrialists. The HAL also denoted a lack of organization among the steamship lines and lamented the absence of a lobbyist in Washington. Without urgent action, the much better organized labor union would pass the bill. ${ }^{23}$

That shipping companies managed to retain such level of lobbying activity despite the disruptive impact of the war on their business is remarkable. Yet their weakened position combined with the downfall of immigrant group protests and the lack of support from employers and industrialists turned the tide in favor of labor unions and the IRL. In 1917, Congress overrode Wilson's second veto. 23 years after being first introduced and having passed one of the Houses of Congress 17 times, the literacy test was finally enacted. By then, literacy had strongly increased in southern and eastern Europe, turning the bill into a more symbolic victory. Therefore, the IRL immediately used the momentum to work on a restrictive bill based on national origins. ${ }^{24}$ By the time the shipping interests regained some normality reestablishing cartel agreements, Congress approved the Quota Acts, greatly restricting the volume of immigration on nationality and ethnic backgrounds discriminating against eastern and southern Europeans. Shipping companies believed these to be temporary relying on improved economic conditions to increase the demand for labor and turn the tide. Instead with the crash of 1929, the transatlantic migrant market completely collapsed, forcing many passenger shipping companies to bankruptcy and with it ending its pivotal role in shaping early US immigration reform.

${ }^{23}$ MAR, HAL, Letters November 11, 1913, December 25, 1915; January 12, June 9, 17, and 21, and July 5, 1916. 318.03 Passage, 160, 232-35, 257.

${ }^{24}$ Minutes of IRL meeting, March 23, 1917. HOCP, Immigration 1789-1930. 


\section{CONCLUSION}

If we project Freeman's interest group-driven model through a historical lens, this article proposes that the most constant, long-established and hence driving force behind the pro-immigration lobby during the long nineteenth century was not employers or migrant communities but shipping companies. Their lobby efforts can be traced back to the sailship era, but such efforts were professionalized as restrictive pressures grew adapting to institutional changes during the Progressive Era. Their influence on migration policies not only dates back longer, they were also more consistent than employer interests that were more reluctant to defend the cause during economic downturns. Shipping companies never backed down, not even under growing anti-trust pressures. They stimulated the mobilization of the migrant communities to strengthen both their inside top-down and outside bottom-up lobby campaigns. Their efforts first centered on the old-stock communities with greater political power to later shift to newer immigrant communities. Protest of older communities gave new immigrant groups who were the targets of restrictions time to grow and organize. The shipping lobby also constantly sought the support of employers and capitalists with whom they coordinated the efforts.

The shipping interest's perspective corroborates the premise that those who benefit from immigration had greater incentives to organize than those who carried the cost. No interest group benefitted more directly from migration. The shipping lobby's top-down efforts first stalled US immigration reforms through diplomats using the rhetoric that migration was a matter of international trade. Yet by the 1880 s, the conviction that immigration was a matter of national sovereignty became generally accepted. Supranational influences on migration policies decreased, leaving the debate to the national domestic arena as in Freeman's model. Diplomats disappeared from the lobbying scene and were replaced by professional lobbyists. These intermediaries circulated vital information between the shipping lobby and policy makers, allowing the former to react quickly to provide the latter with the necessary incentives, strategies, arguments, and bills to oppose restrictions. They stalled and attenuated new reforms using institutional changes and the growing need for expert advice by pushing for congressional investigation committees of unprecedented scale to their advantage. The shipping lobby was initially fragmented and restricted to inside top-down activities. Shipping cartels and 
mergers collectivized the shipping lobby efforts which during the 1890 s expanded to bottom-up strategies and the mobilization of other interest groups. For the bottom-up strategies, the shipping lobby mainly counted on journalists and migrant communities. It financed and sometimes even established national and cross-ethnic associations, providing crucial citizen support which voiced their protest on the streets, in the press, and in Washington. To stir the public in favor of immigration, the shipping lobby hired journalists to screen the press, spread propaganda in newspapers, magazines, and scientific journals. Their advertising campaigns and the migrant-agent network procured the shipping lines close ties with mass media.

The assumption that the public followed the "Iron law" of being in favor of restrictions is questionable. Research on public opinion is nearly nonexistent for this period. Polls are not available, yet a political claimsmaking analysis based on newspaper sources should reveal new insights. This study highlights that interest groups attached a growing importance to influence the public sentiment as an integral part of their lobby campaigns. The shipping lobby spread propaganda to influence the public in general, yet the core of its campaigns was directed to segments based on geographic, sectarian, and ethnic determinants. They fed the political claim that restrictions were a scheme from eastern interests to hamper the development of the South and the West. When this assertion lost support, they shifted their focus on sectarian differences portraying the restrictions as a means to oppress the Catholic and Jewish elements. Linked to those are the ethnic differences which were instigated by representing the literacy test as an Anglo-Saxon scheme to repress other ethnic groups. By playing on the ethnic sentiments of immigrant communities, the shipping lobby managed to mobilize a visible citizen support on the streets and in Washington, whose electoral vote gained importance in political campaigns. This support is something that restrictionists lacked. Although the labor unions represented their members in Washington, these never took the streets to demand restrictions. The IRL ran propaganda campaigns to stir the public sentiment, yet the elitist movement was unable to mobilize citizen support. That the public endorsed their claims is an assumption that has no empirical grounds. This paper conversely suggests that civil society was a much stronger source of liberalism than restrictionism, corroborating Geddes and Statham's findings (2006, 255) that pro-migrant lobby strongly colonizes the "organized public." 
However, these researchers also strongly play down the importance of interest groups and public opinion on policy outcomes which they see as being determined in a relatively autonomous way by political elites that favor restrictions. The voting patterns on the literacy test in Congress confirm the restrictive stance of a majority of the legislators. So why then did it take 23 years to pass the test? Part of the answer lays in the institutional system that requires a majority to pass reforms, whereas a minority is enough to prevent or stall legislation. This article claims however that the intervention of the shipping lobby was crucial to maintain a minority big enough to oppose restrictions. If legislators felt relative autonomy in their decisions, the pro-immigration lobby made sure to remind them directly and indirectly, by mobilizing part of their constituents, that this could come at an electoral cost. By organizing the immigrant groups, the shipping lobby made this threat tangible. Not until the Great War totally disrupted the shipping lobby and the opposition of migrant communities, did restrictions finally pass. As Suro $(2009,220)$ observed on today's immigration reforms, political mobilization is short and intense and aimed at blocking rather than advocating legislation. While the American public is beset in ambivalence regarding migration, the most vocal segments of the population are those espousing minority views. Going by historical evidence, the current stalemate on immigration may still drag on for a while, but there is a need for more research looking at actors that operate beneath the surface. Transport companies may no longer earn most of their revenues from migrant traffic, yet migration policies still have a major impact on the mobility of their passengers, now mainly consisting of tourists. The fact that most irregular migrants come in as tourists has subjected this class of passengers to much more scrutiny. Also, to this day, authorities use transport companies as an integrated part of the border enforcement system. Therefore, the transport sector still has very good reasons to influence current debates, laws and their enforcement but their role remains absent in scientific research.

\section{REFERENCES}

\section{Primary Sources}

Belgian Ministry of Foreign Affairs Archives

Emigration, no. 2961 I, ouvriers Belges aux Etats-Unis: généralités 1883-1908.

Dutch National Archives

2.05.13 Gezantschap USA 1814-1940, no. 210 
Municipal Archives Rotterdam (MAR), Holland-America Line (HAL)

318.02, Directors, no. 112-121, correspondence 1883-1917

318.03, Passage, 49-58, 97, 160, 190, 221, 225, 227, 252; correspondence 1912-1917

318.04, Passage 72-77 and 221-226, correspondence 1887-1911

National Archives Washington (NAW), Immigration and Naturalization Service, RG 85

51632/13, Immigration legislation: National Liberal Immigration League 1907-1916.

52600/13, Investigation at Ellis Island 1909.

53854.39 A-E, Immigration WWI 1914-1919.

Harvard Open Collection Program (HOCP) (http://ocp.hul.harvard.edu/immigration/)

Immigration to the United States 1789-1930: Immigration Restriction League.

\section{Secondary Sources}

Bemis, E.

1888 "Restriction of Immigration." Andover Review 9 (1):251-64.

Bittlingmayer, G.

1996 "Antitrust and Business Activity: The First Quarter Century." The Business History Review 70(3):363-401.

Bonjour, S.

2011 "The Power and Morals of Policy Makers: Reassessing the Control Gap Debate."

Boyce, G. International Migration Review 45 (1):89-122.

1995 Information, Mediation and Institutional Development: The Rise of Large Scale Enterprise in British Shipping 1870-1919. Manchester: Manchester University Press.

Chandler, W.

1893 "Shall Immigration be Suspended?" North American Review 79 (1):1-8.

Chandler, A.

1977 The Visible Hand: The Managerial Revolution in American Business. Cambridge: Cambridge University Press.

Clemens, E.

1997 The People's Lobby: Organizational Innovation and the Rise of Interest Group Politics in the United States, 1890-1925. Chicago: University of Chicago Press.

Cohn, R.

2005 "The Transition from Sail to Steam in Immigration to the United States." The Day, J. Journal of Economic History 65 (2):469-95.

2002 "Credit, Capital and Community: Informal Banking in Immigrant Communities in the United States 1880-1924." Financial History Review 9 (1):65-78.

Deltas, G., K. Sefres, and R. Sicotte

1999 "American Shipping Cartels in Pre-World War I Era." Research in Economic History 19 (1):1-38.

Ewen, $S$.

1976 Captains of Consciousness: Advertising and the Social Roots of the Consumer Culture. New York: McGraw-Hill.

Facchini, G., A. Mayda, and P. Mishra

2011 "Do Interest Groups Affect US Immigration Policy?" Journal of International Economics 85 (1):114-28. 
Feys, T.

2008 "Prepaid Tickets to Ride to the New World: The New York Continental Conference and Transatlantic Steerage Fares 1885-1895." Revista de Historia Economica 26(2):173-204.

2010 "The Visible Hand of Shipping Interests in American Immigration Laws." Tijdschrift Voor Sociale en Economische Geschiedenis 7(1):38-62.

2013 The Battle for the Migrants: The Introduction of Steamships on the North-Atlantic and its Impact on the European Exodus. St. John's: International Maritime Economic History Association.

Freeman, G.

1995 "Modes of Immigration Politics in Liberal Democratic States." International Migration Review 29 (4):881-902.

2002 "Winners and Losers: Politics and the Costs and Benefits of Migration." In Western European Immigration and Immigration Policy, edited by A. Messina, 77-96. Westport: Praeger.

, and A. Kessler

2008 "Political Economy and Migration Policy." Journal of Ethnic and Migration Studies $34(4): 655-78$.

Geddes, A., and P. Statham

2006 "Elites and the 'Organised Public': Who Drives British Immigration Politics and in Which Direction?” West European Politics 29 (2):248-69.

Goldin, C.

1994 "The political economy of immigration restriction in the United States 18901921." In The Regulated Economy: A Historical Approach to political economy, edited by C. Goldin and G. Libecap, 223-57. Chicago: University of Chicago Press.

Greenhill, R.

1998 "Competition or cooperation the Global Shipping Industry: The origins and impact of the Conference system for British Shipowners before 1914." In Global Markets, edited by D. Starkey and G. Harlaftis, 55-71. St. John's: IMEHA.

Guglielmo, T.

2003 White on Arrival: Italians, Race Colour and Power in Chicago 1890-1945. New York: Oxford University Press.

Hall, P.

1912 "The Future of American Ideals." North American Review 98 (1):94-102.

1913 "The Recent History of Immigration and Immigration Restriction." Journal of Political Economy 22 (8):735-51.

Heffer, J., and W. Wilson

2002 The United States and the Pacific: History of a Frontier. Notre Dame: University of Notre Dame Press.

Higham, J.

1955 Strangers in the Land: Patterns of American Nativism 1860-1925. New Brunswick: Rutgers University Press.

Hourwich, I.

1912 Immigration and Labor: The Economic Aspects of European Immigration to the United States. New York: G.P. Putnam's \& Sons. 
Hutchinson, E.

1981 Legislative History of American Immigration Policy 1798-1965. Philadelphia: University of Pennsylvania.

Jones, M.

1989 "Aspects of North Atlantic Migration: Steerage Conditions and American Law, 1819-1909.” In Maritime Aspects of Migration, edited by K. Friedland, 321-31. Cologne: Bohlau.

1992 American Immigration. Chicago: University of Chicago Press.

Just, M.

1988 Ost und Sudosteuropaische Amerikawanderung 1881-1914. Stuttgart: Steiner Verlag. Keeling, D.

1999 "The Transport Revolution in Transatlantic Migration, 1850-1914." Research in Economic History 19 (1):39-74.

2012 The Business of Transatlantic Migration between Europe and the United States, 1900 King, D. 1914. Zürich: Chronos Verlag.

2000 Making Americans: Immigration, Race and Origins of the Diverse Democracy. Cambridge: Harvard University Press.

Klebaner, B.

1958 "State and the Local Immigration Regulation in the United States before 1882." International Review of Social History 3 (2):269-359.

Klüver, $\mathrm{H}$.

2013 "Lobbying as a Collective Enterprise: Winners and Losers of Policy Formulation in Lissak, R. the European Union.” Journal of European Public Policy 20 (1):59-76.

1994 "The National Liberal Immigration League and Immigration Restriction, 1906Martin, S. 1917." American Jewish Archives 46 (2):197-246.

2003 "The Politics of US Immigration Reform." The Political Quarterly 74 (1):132-49.

Mora, M.

2005 El Poder De La Conversacion. Buenos Aires: Editorial La Crujia.

Murken, E.

1922 Die grossen transatlantischen Linienreederei-Verbande, Pools und Interessengemeinschaften bis zum Ausbruch des Weltkrieges: Ihre Entstehung, Organitsation und Wirksamkeit. Jena: G. Fischer.

Petit, J.

2010 The Men and Women We Want: Gender, Race, and the Progressive Era Literacy Test Debate. Rochester: Rochester University Press.

Powderly, T.

1888 “A Menacing Irruption.” North American Review 74 (2):165-74.

Ripley, W.

1898 The Races of Europe: A Sociologic Study. New York: D. Appleton \& Co.

Roediger, D.

2005 Working towards Whiteness: How America's Immigrants became White. New York: Basic Books. 
Senner, J.

1894 "How We Restrict Immigration." North American Review 80 (4):494-9.

1897 "The Immigration Question." Annals of the American Academy of Political and Social Science 10 (1):1-19.

Suro, R.

2009 "Promoting Stalemate: The Media and US Policy on Migration." In Migration, Public Opinion, and Politics, edited by M. Bertelsmann Stiftung, 185-221. GuterTichenor, D. sloh: Verlag Bertelsmann Stiftung.

2002 Dividing Lines: The Politics of Immigration Control in America. Princeton: Princeton University Press.

Ville, $S$.

1990 Transport and the Development of the European Economy 1750-1918. London: Macmillan.

Ward, R.

1907 “The New Immigration Act." North American Review 93 (4):587-93.

1910 "National Eugenics in Relation to Immigration." North American Review 96 (1):56-67.

Weil, P.

2003 "Races at the gate: Racial distinctions in immigration policy." In Migration Control in the North Atlantic World, edited by A. Fahrmeir, O. Faron, and P. Weil, 27197. New York: Berghahn Books.

Zeidel, R.

2004 Immigrants, Progressives, and Exclusion politics: The Dillingham Commission 19001927. Dekalb: Northern Illinois University Press.

Zolberg, A.

2006 A Nation by Design: Immigration Policy in the Fashioning of America. Cambridge: Harvard University Press. 